\title{
Does the Lord Speak with a Forked Tongue? Solutions for Unity in a Diverse Biblical Corpus
}

\begin{abstract}
Does the Bible present a unified message from God to humanity? This paper is an attempt to undertake the task set forth by biblical scholar G. Ernest Wright, who said: "The question of the unity of the Bible's message is one that will never be satisfactorily solved, though it is one which every generation of Christians must seek to solve." This investigation, while framed as a "personal attempt," looks at the biblical-theological issue of unity and diversity within the Bible to try to form some theologically synthetic answer to the above question. This investigation dialogues with the history of biblical interpretation by first looking at issues related to diversity in the New Testament ("Micro-diversity") and then to the Bible as a whole ("Macrodiversity") to see if we can understand a "whole Bible biblical Theology." Finally, this paper explores some of the implications of the answers to these questions for the modern Christians.
\end{abstract}

\section{Introduction}

As a child, being raised in a Christian home and growing up in the church, I always thought of the Bible as a unified message from God to humanity. ${ }^{1}$ As a Christian today, this is a presupposition to which I still hold, albeit with less naiveté and with a greater deal of theological synthesis. G. Ernest Wright said, “The question of the unity of the Bible's message is one that will never be satisfactorily solved, though it is one which every generation of Christians must seek to solve."2 This paper is my personal attempt at accomplishing that task.

Early in theological education, diversity in the Bible is pressed upon students, even within distinctively Christian institutions. ${ }^{3}$ This is primarily due to the rise in critical biblical scholarship over the past few centuries. ${ }^{4}$ We speak of the "theology of the Pentateuch," or “John's theology," or "Paul's theology," etc. The legacy of critical biblical scholarship in recent

\footnotetext{
${ }^{1}$ Though I would not have used that language.

${ }^{2}$ G. Ernest Wright, "The Unity of the Bible," Scottish Journal of Theology 8 (1956): 337-352.

${ }^{3}$ See also, W. Hulitt Gloer, "Unity and Diversity in the New Testament: Anatomy of an Issue," Biblical Theology Bulletin 13 (1983): 53-58.

${ }^{4}$ See also, Gloer, "Unity and Diversity," 54. See also, Otto Betz, "The Problem of Variety and Unity in the New

Testament," Horizons in Biblical Theology 2 (1980): 3-14.
} 
centuries has certainly allowed for deeper levels of biblical study. However, it has

simultaneously left open the question of theological unity in the Bible:

[Regarded] not as a repository of eternal truths but as a collection of writings arising out of and addressing particular situations and contexts...no longer seen as a divinely guaranteed unity but as a disparate collection of materials that have points in common, but are also characterized by significant diversity. ${ }^{5}$

The goal of this paper is to explore the issue of diversity and unity in the Bible.

Specifically, this paper will first focus on the issue of diversity internal to the New Testament, named here "micro-diversity." Second, this paper will look at the issue of "macro-diversity" pertaining to "whole Bible biblical theology,"7 or rather, the relation of the two testaments. Beyond simply stating the "problem," this paper will also examine how biblical theologians have attempted to solve both of these problems. Finally, this paper will explore the implications of these issues for those Christians who consider the whole Bible to be God's revelatory Word to humanity.

\section{The Problem - Micro-diversity \& New Testament Issues:}

The problem, in general, of biblical diversity has been aptly stated as a question and answer by James D.G. Dunn: "Do the biblical writings speak with a single voice, present a wholly consistent testimony? The immediate answer must again be, No!"8

\footnotetext{
${ }^{5}$ David Wenham, "Appendix: Unity and Diversity in the New Testament" in A Theology of the New Testament (By George Eldon Ladd. Rev. ed. Ed. Donald A. Hagner; Grand Rapids: Eerdmans, 1993), 684-720.

${ }^{6}$ The focus on the New Testament in this paper is purely out of personal interest. I am sure that the fruit of recent study regarding unity and diversity in the New Testament could be replicated for Old Testament study (See e.g. the essays by Jorge Pixley, Ellen van Wolde, Maricel Mena Lopez, and Johanna Stiebert in Freyne, Sean, and Ellen van Wolde, eds. The Many Voices of the Bible (Concilium 2002:1. London: SCM Press, 2002).) Any mention of the Old Testament here is in regards to unity or diversity with its counterpart, the New Testament.

${ }^{7}$ Scott J. Hafemann and Paul R. House, eds., Central Themes in Biblical Theology: Mapping Unity and Diversity (Grand Rapids: Baker Academic, 2007), 15.

${ }^{8}$ James D.G. Dunn and James P. Mackey, eds., New Testament Theology in Dialogue (Philadelphia: Westminster, 1987), 9.
} 
Historically, there have been biblical scholars who have maintained on the basis of a diverse biblical corpus that a single biblical theology is not possible. ${ }^{9}$ However, the lack of unity is a problem for those who would be included in the category of "believing scholarship," as it is a problem for the Christian church at large. For believing scholarship and the church, under the assumption that the Bible is God's revelatory Word to humanity, there must be some unifying element lest we conclude that "the Lord speaks with a forked tongue." ${ }^{10}$ Of course, a person who does not share this a priori assumption is not bothered by such diversity. He or she would allow for complete diversity within the biblical corpus simply as a historical case study of the development and solidification of the tradition of early Christianity.

Assuming the position that the Bible is God's revelatory Word to humanity, it may be easy for people from a position of faith to ascribe a coherent unity to the Bible based solely on "a monistic understanding...imposed on the Bible in the name of canonical orthodoxy." 11

However, the biblical corpus contains at least 66 different texts from many different authors and redactors. The New Testament itself, with its 27 books, contains at least eight different authors by a very conservative count. ${ }^{12}$

Tied to the question of diversity in the New Testament is the question of the nature of "orthodoxy." Of course "orthodoxy," as it came to be solidified in the church in the second and

\footnotetext{
${ }^{9}$ See, C. Marvin Pate, et al., The Story of Israel: A Biblical Theology (Downers Grove: IVP Academic, 2004), 1316.

${ }^{10} \mathrm{I}$ owe this imagery to the class lectures given by Scott J. Hafemann for his class Faith, Hope and Love: A Biblical Theology, available by Semlink at Gordon-Conwell Theological Seminary, South Hamilton, Massachusetts.

${ }^{11}$ Freyne, and van Wolde, The Many Voices, 7.

${ }^{12}$ This count is given by Wenham, "Appendix: Unity and Diversity," 684. A.M. Hunter has said 12 different authors (See, A.M. Hunter, The Unity of the New Testament: One Lord, One Church, One Salvation (London: SCM Press, 1943), 11. For still a conservative count, but taking into account more fully the fruits of scholarship, I can determine 11 different authors: 4 Gospel authors (one of which has written Acts as well), Paul (granting, for the sake of argument, all 13 letters in the Pauline corpus), the author of Hebrews, James, the Petrine Epistles, Jude (considering it distinct enough from 2 Peter), the Johannine Epistles, and Revelation. Of course this number will only increase as we debate the authenticity of the latter Pauline letters and some of the other texts in the latter New Testament, not to mention the various redactors possible within each text. The number could be a lot more than 27 !
} 
third centuries, played a major role in the canonical process. But can there be identified, then, "orthodoxy" in the biblical canon as it came out in late first century Christianity? This is the first task of Dunn's study on unity and diversity, to inquire as to the nature of "Orthodoxy" during the New Testament period.

Dunn, in his definition of orthodoxy, states that it "implies that a clear distinction can be drawn between truth and error. 'Orthodoxy' implies that there is a pure uncontaminated faith, a correct teaching; all variations from it are then at once 'heretical' in greater or less degree."13 Thus he poses the question: "Was there ever in fact such an orthodoxy? - a single clearly defined faith which separated Christian from heretic?"14 As Dunn pursued the answer to this question, he found, following the foundational work of Walter Bauer, that,

[There] was no "pure" form of Christianity that existed in the beginning which can properly be called "orthodoxy'... [despite the classical view from Christianity that] there always has been a single, pure faith reaching right back to the apostles, that the Church has kept the teaching of Jesus and the apostles undefiled. ${ }^{15}$

The case for a diversity of Christian groups has been well built and maintained by scholarship following Walter Bauer's Orthodoxy and Heresy in Earliest Christianity, and supported by two fields of $20^{\text {th }}$ century research: history of religions and the history of earliest Christian traditions. ${ }^{16}$ David Wenham has provided a summary list of the possible groups:

There was a strongly Jewish Christianity associated particularly with Jerusalem; there was a Hellenistic Christianity, often tending toward Gnosticism; there was an apocalyptic Christianity with a strong emphasis on an imminent end; and there was eventually, catholic Christianity. ${ }^{17}$

\footnotetext{
${ }^{13}$ James D.G. Dunn, Unity and Diversity in the New Testament: An Inquiry into the Character of Earliest Christianity $\left(2^{\text {nd }}\right.$ ed. London: Trinity Press International, 1990), 1.

${ }^{14}$ Ibid., 2.

${ }^{15}$ Ibid., $2,3$.

${ }^{16}$ See, Ibid., 3-4

${ }^{17}$ Wenham, "Appendix: Unity and Diversity," 687. This list also follows the second part of Dunn's work Unity and Diversity, chapters 11-14.
} 
This list can be nuanced further as there was certainly a distinction between non-Pauline Hellenistic Christianity and Pauline Hellenistic Christianity. ${ }^{18}$ Likewise, within Jewish Christianity, the Johannine community seemed to be something wholly separate (at first) from the mainstream of Jewish Christianity focused around Peter and the Jerusalem church. ${ }^{19}$ There were also Hellenistic-Jewish-Christian communities, as can be seen by the address of the Epistle of James. The diversity of thought between these different groups has been reflected in the texts of the New Testament.

The term applied in this paper to this diversity in the New Testament is "microdiversity." This term is used for two reasons. Although it does not imply that the issues of diversity in this sense are minute or unimportant, it does presuppose that a certain level of unity can be achieved with regard to the New Testament. The second reason is to distinguish between issues of diversity relating to the Bible as a whole; this is termed "macro-diversity."

The "micro-diversity" among the different perspectives in the New Testament is detectable even from a cursory reading of the various texts. These major differences include theological differences between the Synoptic Gospels themselves, differences between the Synoptic traditions in general and the Johannine tradition, differences between the Jesus traditions in general and the Pauline corpus, internal differences within the Pauline corpus (at the Pauline vs. deutero-Pauline level, and within the undisputed collection ${ }^{20}$ ), differences between the Pauline letters and the Catholic Epistles, differences between the groups of letters or single

\footnotetext{
${ }^{18}$ See, Rudolph Bultmann, Theology of the New Testament ( 2 vols. Translated by Kendrick Grobel. Waco, Baylor University Press, 2007), 63-183.

${ }^{19}$ See, Raymond E. Brown, The Community of the Beloved Disciple. New York: Paulist Press, 1979.

${ }^{20}$ For example, there is an emphasis on the parousia in the Thessalonian epistles that is not found in the other Pauline epistles. See below. See also, James D.G. Dunn, The Theology of Paul the Apostle (Grand Rapids:

Eerdmans, 1998), 298.
} 
standing letters of the Catholic Epistles, and finally, the differences between the rest of the New Testament and the Book of Revelation. ${ }^{21}$

\section{Possible Solutions}

Perhaps the most obvious and fundamental way to deal with the issue of diversity is to find points of commonality among the different perspectives in the New Testament. Or to take the idea further, find the core unifying element in the New Testament. This task is important not simply for the scholar and his understanding of the New Testament period. As G. Ernest Wright's comment above urges, this task is important also for the Christian who wishes to make sense of the Bible as God's revelatory Word. However, problems lay in this task as well. Scott Hafemann has stated, "the attempt to isolate such a theme has proved to be too specific to gain a consensus or too general to be of explanatory power.",22

There have been many different "centers" proposed as the key to New Testament theology, including Jesus Christ, the Gospel, salvation, eschatology, faith, salvation history, justification, the Kingdom of God, and covenant. ${ }^{23}$ Here it is possible to see the validity of Hafemann's criticism. For example, is eschatology, despite its immense importance, too specific an idea to be the center? Or is Jesus Christ too broad? Ordoes emphasizing faith as the center detract from the understanding of Jesus Christ's person and work ${ }^{24}$ Of course, all of these ideas

\footnotetext{
${ }^{21}$ See also, Dunn, and Mackey, NTT in Dialogue, 9-10. See also, Dunn, Theology of Paul, 305. Even in his defense of the unity of the New Testament, A.M. Hunter excludes Revelation from his study claiming that it is "more Jewish than Christian" (see, Hunter, The Unity of the New Testament, 18.).

${ }^{22}$ Scott J. Hafemann, "The Covenant Relationship," in Central Themes in Biblical Theology: Mapping Unity and Diversity (Edited by S.J. Hafemann and P.R. House. Grand Rapids: Baker Academic, 2007), 20-65. Though in this statement, he is referring to finding a unifying element to the entire Bible.

${ }^{23}$ Two works that have summarized multiple concepts proposed as a center are John Reumann, Variety and Unity in New Testament Thought (New York: Oxford University Press, 1991), 27-33, and Gloer, "Unity and Diversity," 55-56.

${ }^{24}$ This criticism could certainly be leveled against Bultmann's methodology, despite the wonderful comments he has made regarding the nature of faith. See below. (See also, Bultmann, Theology of the New Testament, 3, $314-329$.
} 
are inextricably intertwined with and influence each other. All could be defended as appropriate centers of New Testament theology.

The "kerygma" stands as the most popular of ideas for the center of New Testament theology among scholars. Kerygma is very simply defined as the essential message of the apostolic preaching. ${ }^{25}$ C.H. Dodd has summarized what is meant by kerygma in his foundational work, The Apostolic Preaching and its Developments, in terms of seven essential elements:

The prophesies are fulfilled, and the new Age is inaugurated by the coming of Christ. He was born the seed of David. He died according to the Scriptures, to deliver us out of the present evil age. He was buried. He rose on the third day according to the Scriptures. He is exalted at the right hand of God, as Son of God and Lord of quick and dead. He will come again as Judge and Saviour of men. ${ }^{26}$

A.M. Hunter, in his defense of the unity of the New Testament, has simplified the kerygma even further in a threefold manner: the message being the fulfillment of Old Testament prophecy, historical exposition of Jesus' life, teaching, death, and resurrection, and repentance and acceptance of forgiveness of sins in Jesus. ${ }^{27}$ For Hunter, the kerygma is the "golden thread" that runs through the pages of the New Testament and provides a great example of the unity of the New Testament. ${ }^{28}$

Two prominent $20^{\text {th }}$ century scholars, Rudolph Bultmann and Joachim Jeremias, have also emphasized the importance of kerygma as it relates to the early church. Bultmann stressed that the kerygma in the earliest church was foundational to the understanding of Jesus postEaster. He stated that, "the kerygma of Jesus as messiah is the basic and primary thing which

\footnotetext{
${ }^{25}$ Though as Dunn has summarized, there was a debate between Dodd and Bultmann regarding whether or not kerygma should be identified in terms of the content of the preaching or as the act of preaching. This paper will assume the former. See, Dunn, Unity and Diversity, 11-12.

${ }^{26}$ C.H. Dodd, The Apostolic Preaching and its Developments (London: Hodder \& Stoughton, 1936), 28.

${ }^{27}$ Hunter, The Unity of the New Testament, 24-25.

${ }^{28}$ Ibid., 30
} 
gives everything else — the ancient tradition and Jesus' message — its special character."29

According to Jeremias, "we know only the Christ of the kerygma, where Jesus is clad in the garb of myth...What matters is the Christ of the kerygma, Christianity began at Easter." ${ }^{, 30}$ In the rest of his study, Jeremias shows how the kerygma had been applied in three ways: understanding Jesus' sacrificial death, justification by faith, and understanding Jesus as the revealing Word. ${ }^{31}$ For both Bultmann and Jeremias, the foundation of the primitive church can be found in the kerygma, despite the diversity of early Christian groups.

In his study, Unity and Diversity in the New Testament, Dunn also champions the kerygma as the unifying element. However, Dunn distinguished between kerygma and kerygmata. ${ }^{32}$ In the same way his study inquired into the nature of a single orthodoxy in the New Testament, he inquired into the unity and diversity within the kerygma, recognizing that that there would be differences in different contexts. ${ }^{33}$ After summarizing the diversity in kerygmatic structures in the Synoptic Gospels, Acts, Paul, and John, he concluded that they all share components of a "core kerygma": proclamation of the risen Jesus, a call for faith and commitment to this proclamation, and the promise of results of that faith (spirit, salvation, etc.). ${ }^{34}$ How does the kerygma being identified as the center of New Testament theology measure up to Hafemann's criticism of finding a unifying element? Is it too narrow to "gain a

\footnotetext{
${ }^{29}$ Bultmann, Theology of the New Testament, 42. While kerygma was certainly an important concept in Bultmann's understanding of the New Testamenthis statement that, "Every assertion about God is simultaneously a statement about man and vise versa" (191) has led Gloer to conclude that for Bultmann, the center of New Testament theology was anthropology (see, Gloer, "Unity and Diversity," 55.

30 Joachim Jeremias, The Central Message of the New Testament (New York: Charles Scribner's Sons, 1965), 30. Of course, here can be seen in his comment some of the more "liberal" conclusions coming out of the then trending historical Jesus studies.

${ }^{31}$ See, Jeremias, The Central Message of the New Testament, chapters 2-4.

${ }^{32}$ Dunn, Unity and Diversity, 11.

${ }^{33}$ See, Ibid., 12. Dunn states further: "Any attempt to find a single, once-for-all, unifying kerygma is bound to fail. For the concrete situation always calls forth a more closely defined and larger kerygma... which in the concrete situation cannot be boiled down to the unifying core without losing its meaning and its relevance to the concrete situation," Dunn, Unity and Diversity, 32.

${ }^{34}$ See, Ibid., 30
} 
consensus"? Is it too broad to be of "explanatory power"? At first glance, it may seem that understanding the kerygma as the center risks falling right into Hafemann's criticism; too broad and lacking in explanatory power. The word itself is rather erudite, obscure and perhaps meaningless to the majority of laymen in the church. However, it is the opinion here that with a little work, this can be a concept of significant value as a center of New Testament theology. It is a broad concept, but its broadness allows for a comprehensive and inclusive understanding of what was important in the message of the earliest church. Therefore, it is broad enough to include the concepts of Jesus, his message of the Kingdom, his death and resurrection, and incorporate concepts of faith, eschatology, etc. All of the elements that could themselves be defended as centers are all interrelated ideas. As James Barr has suggested, there may be a "plurality of centers." ${ }^{.35}$ The idea of the kerygma as the center has the ability to carry the other interrelated ideas with it. Once this is understood, it certainly has explanatory power as the one thing that all first century Christians were concerned with, despite the diversity of perspectives and a kerygma that may have looked different in differing contexts.

Allowing a meaningful center to New Testament theology is certainly helpful to establishing unity in the New Testament. However, it only solves half of the problem. The New Testament texts may all share a certain emphasis on the elements of kerygma, for example, but what of the nature of diversityand all the differing theological perspectives listed above?

As mentioned above, the rise of critical biblical scholarship has left open the door to the question of the unity of the Bible by highlighting the idea of diversity. However, in doing so, it has also simultaneously begun to answer the question of diversity. The focus on diversity within the different perspectives of the New Testament has allowed for studies on the different contexts of the perspectives. Critical studies regarding authorship, date, provenance, and audience have

\footnotetext{
${ }^{35}$ James Barr, “Trends in Biblical Theology,” Journal of Theological Studies 25 (1974): 265-282.
} 
helped to explain differing theological perspectives within the New Testament. Understanding issues of context is the context where an appropriate understanding of diversity in unity can be achieved.

For example, scholars have noted the "striking" emphasis on eschatology, specifically the parousia, within the Thessalonian epistles, and the lack of emphasis on that subject in the other Pauline writings. ${ }^{36}$ Why is this the case? Allowing for the possibility that Paul's theology may have shifted over time due to the delay of the parousia, ${ }^{37}$ the obvious reason is that, "the [letters] were occasioned by particular crises. ${ }^{, 38}$ The occasions for Galatians, or Philippians, or Romans, for example, did not necessitate such an emphasis on the subject. Does this mean that interpreters cannot declare a unity with regard to Paul's view of the second coming? According to Dunn, "It can be claimed with confidence that the coming again of Christ was a firm part of Paul's theology. ${ }^{, 39}$

A favorite example commonly used to point out the diversity in the New Testament is to set up Paul's view of justification by faith against James's view of “justification by works." Understanding the two positions in this dichotomous way is what led Martin Luther to reject the Epistle of James. ${ }^{40}$ It is possible to see these two seemingly inharmonious streams of thought on the subject as in continuity with each other. As scholars have studied both Paul and James, they have found not a unity in conflict, but rather different perspectives due to the fact that they were written for different audiences, some of whom may have been misinterpreting Paul's Gospel.

\footnotetext{
${ }^{36}$ Dunn, Theology of Paul, 298.

${ }^{37}$ Ibid., 298, 310.

${ }^{38}$ Ibid., 301.

${ }^{39}$ Ibid., 313. Dunn's "canon within a canon" for his study on Paul highlights Romans, which he claims is "the most mature statement of his theology" (298). Yet, he can still make the statement above with confidence. His chapter on the matter does acknowledge the difficulties with this task.

${ }^{40}$ See below regarding Luther's Law-Gospel contrast.
} 
They had different emphases: "Paul's on salvation by free grace and James's on faith in action. ${ }^{41}$

Similarly, the Synoptic Gospels have been demonstrated to emphasize diversity, especially after a couple centuries of "historical Jesus" investigation. On one level, this is certainly understandable. It is one thing for Paul and James to have differing views on an abstract theological point. But different perspectives in the gospels are takes on the same concrete people and events. This is also one area where critical scholarship has excelled due to forms of inquiry such as form, source, and redaction criticism. As scholarship investigated the Evangelists differing theologies in their interpretations of Jesus, it was able to give insight into why a particular theological concern arose. A typical example is the differing attitudes toward the Law found in Matthew and Mark, the former typically understood as having a more favorable view of the Law. However, David Wenham has argued that there is a diversity of thought even within Matthew's Gospel on the subject and that the audience was a determining factor "being concerned to portray Jesus as the fulfillment of the Law and the Prophets." ${ }^{.42}$

More will be said in the conclusion below. However it is worth noting here that a unity of the New Testament can be achieved by finding a unifying element, a "golden thread" running through all of the texts. Diversity of perspectives, either within a single work, author, or across differing early Christian groups serve as a mirror into the modern church, where in different contexts different theological perspectives are born. However, in all cases, there was a certain commitment to the kerygma (itself varying in different contexts) to preach the message of Jesus. In cases of diversity (like those examined above), understanding why differences arose due to context can help modern interpreters find the unity in the midst of diversity.

\footnotetext{
${ }^{41}$ Wenham, “Appendix: Unity and Diversity," 692.

${ }^{42}$ Ibid., 694, 714.
} 


\section{The Problem - Macro-diversity \& Whole Bible Issues:}

Diversity may be explained at a micro level (for example, differing portrayals of Jesus among the gospels, or differences in understanding justification, or the near lack of emphasis on the parousia in the non-Thessalonian Pauline epistles) by finding a center of New Testament theology or by emphasizing issues of context (occasion, audience, provenance, etc.). However, the largest single point of diversity in the Bible exists between the two testaments themselves. Dunn has stated that "the more we wish to speak of a biblical theology...the more serious the problem. For all the very important and indeed fundamental continuities between Old Testament and New, we cannot ignore the problem of the discontinuities between the two testaments." ${ }^{, 43}$ It was this observation that caused C. Marvin Pate to state that "[the quandary of relating the two testaments] continues to be the nemesis of biblical theology." ${ }^{\prime 4}$ Dunn has summarized this diversity between the two testaments as,

[The] transformation of the covenant with Israel into a universal covenant, of the Jewish messianic hope into faith in Jesus Christ, of the Sabbath into Sunday, not to mention the abandonment of such key features of the Old Testament law as circumcision, sacrifice and food laws. The problem is that of retaining the Old Testament as Christian Scripture within the canon of the Christian Bible. ${ }^{45}$

In the final part of Dunn's statement can be seen the foundation of the supposed "LawGospel contrast" within the canon which, inherited from Luther, has dominated scholarship throughout the past few centuries of church history. ${ }^{46}$ The issue is exactly how is the Old Testament to be retained as Christian Scripture. As Luther observed the diversity between the two testaments, he employed his hermeneutic of the Law-Gospel contrast to the entire Bible.

\footnotetext{
${ }^{43}$ Dunn and Mackey, NTT in Dialogue, 9.

${ }^{44}$ Pate et al., The Story of Israel, 13 (emphasis added).

${ }^{45}$ Dunn and Mackey, NTT in Dialogue, 9.

${ }^{46}$ See also, Wright, "The Unity of the Bible," 339.
} 
This was his integrative framework. For Luther, the word of God comes in these two forms: Law and Gospel, and it was in this relationship that Luther identified the "center" of the Bible; either as a message of judgment (corresponding to Law) or a message of grace (corresponding to Gospel) ${ }^{47}$ Seen in this light, his famous comments about the Epistle of James are more properly understood. According to Hafemann, the entire protestant world inherited the Law-Gospel contrast in its basic form of a "conflict theory" of biblical theology, "whether in the traditional Lutheran law-gospel perspective, the Reformed understanding of the covenant of works and covenant of grace, or the Dispensational understanding of the dispensations of law and grace." ${ }^{48}$ In these scenarios, the unity of the Bible is only seen through the lens of disunity.

\section{Possible Solutions}

Not content with the "conflict theory" approach to biblical theology, many scholars have attempted to find the unifying "golden thread" that runs through the whole Bible. If kerygma is the integrative framework that unites the diverse texts of the New Testament, what is the integrative framework that unites the entire Bible? Can we have a "whole Bible biblical theology"? ${ }^{49}$ In a similar way to the question of a center of New Testament theology, many themes have been put forward to solve this "quandary." As with the themes of the New Testament, they are often interrelated ideas. They are also hard to test well against Hafemann's criticism as either too narrow to have consensus, or too broad to be of any explanatory power. ${ }^{50}$

\footnotetext{
${ }^{47}$ Berhard Lohse, Martin Luther: An Introduction to His life and Work (Trans. Robert C. Schultz. Philadelphia: Fortress Press, 1986), 157. This helps to shed some light on the above issue regarding Paul and James. Seen in this light (the Law-Gospel contrast), Luther's famous comments about the Epistle of James are more properly understood. His reading of James could only be classified under one category and it certainly was not "Gospel."

${ }^{48}$ Hafemann, "The Covenant Relationship," 30 n31.

${ }^{49}$ Hafemann and House, Central Themes in Biblical Theology, 15.

${ }^{50}$ See again, Hafemann, "The Covenant Relationship," 23.
} 
The goal of this section is to explore a few of the more promising elements of unification for a "whole Bible biblical theology."

Perhaps the most popular and well-known integrative framework of unity in the Bible is "salvation-history" (Heilsgeschichte). In the eighteenth and nineteenth centuries understanding, salvation-history became the dominant way to approach biblical theology when many critical scholars denied that there could even be a biblical theology. ${ }^{51}$ Pate has stated that "Heilsgeschichte...bespeaks the unity of the Bible." ${ }^{.52}$ The idea was revived in the twentieth century by Oscar Cullmann, who,

[Emphasized] the need to summarize the whole Bible along the timeline of redemptive history, instead of reverting to the timeless categories of God, humankind, Christ, church, and last things that has characterized the organization of systematic theology down through the ages." ${ }^{53}$

It has become popular in biblical theology, and for those who champion salvation-history as the integrative framework, to set up biblical history as a "narrative structure reflected in the Deuteronomic Sin-Exile-Restoration pattern." 54 This is commonly abbreviated as "SER." In his essay on the subject, Roy Ciampa contends that there are two CSER structures in biblical history: a national one (Israel) embedded into a global one (humanity). ${ }^{55} \mathrm{C}$. Marvin Pate (and co-authors) use this concept as well as they named their volume The Story of Israel, which is, "God's creation, humanity's sin and resulting exile, and God's mission to restore his people which is a prominent theological theme of Scripture." ${ }^{, 56}$ As to the "quandary" of the relation of the two

\footnotetext{
${ }^{51}$ Pate et al., The Story of Israel, 14-15.

${ }^{52}$ Ibid., 15.

${ }^{53}$ Daniel P. Fuller, The Unity of the Bible: Unfolding God's Plan for Humanity (Grand Rapids: Zondervan, 1992), xv. Fuller ultimately takes this idea of redemptive history as his integrative framework in his study. See also, Roy E. Ciampa, "The History of Redemption" in Central Themes in Biblical Theology: Mapping Unity and Diversity (Eds. S.J. Hafemann and P.R. House. Grand Rapids: Baker Academic, 2007), 254-308.

${ }_{55}^{54}$ Ciampa, "The History of Redemption," 255-256. See also, Pate et al., The Story of Israel, 88-104.

${ }^{55}$ The "C" is due to the fact that the "S" $(\sin )$ presupposes sinning against an established "covenant." See also the section below on Hafemann and the covenant relationship. Ciampa, "The History of Redemption," 256-257.

${ }^{56}$ Pate et al., The Story of Israel, 278.
} 
testaments, the salvation-history approach jettisons the conflict theories that have plagued biblical/theological scholarship and highlights the New Testament authors' emphasis on Jesus as the "central figure for God's new covenant relationship with Israel and the nations.. ${ }^{.57}$ Pate offers a summary of the purpose of the theology of the New Testament as it relates to the Bible as a whole:

The eschatological purpose of God's history with Israel was not to restore the Mosaic covenant. The Prophets were correct, a new covenant is needed. God's spirit would be poured out on all true believers as the Son of Man would show his glory and power. Faithless Israel would remain in spiritual exile, while faithful followers of Jesus, the true believers in God's eschatological purpose would be restored and saved. ${ }^{58}$

The final idea in this summary raises a related issue to salvation-history, that of "who are the people of God?" Having an understanding of the people of God could itself be argued as an integrative framework for uniting the two testaments. ${ }^{59}$ However, "the people of God" discussion has historically created some theological controversy as it is concerned also with the controversial nature of the relationship between Israel and the church, both of who are defined in the Bible as the people of God. ${ }^{60}$ The Old Testament is certainly clear that the historical nation of Israel was the people of God. The foundation of which being the "often-repeated covenant formula 'I will be your God and you shall be my people." ${ }^{61}$ By one count, Israel is referred to the people of God over three hundred times in the Old Testament. ${ }^{62}$

As salvation-history unfolds, focus is on Israel as the people of God in the Old Testament. Returning again to the "quandary," how does the New Testament integrate the concept of the people of God post-Jesus? Here, Ciampa's framework of an embedded CSER

\footnotetext{
${ }^{57}$ Ibid., 280.

${ }^{58}$ Ibid..

${ }^{59}$ See, Elmer A. Martens, "The People of God" in Central Themes in Biblical Theology: Mapping Unity and Diversity. (Eds. S.J. Hafemann and P.R. House. Grand Rapids: Baker Academic, 2007), 225-253.

${ }^{60}$ See, Walter C. Kaiser Jr., Recovering the Unity of the Bible: One Continuous Story, Plan, Purpose (Grand Rapids: Zondervan, 2009), 112.

${ }^{61}$ Martens, "The People of God," 225.

${ }^{62}$ See, Kaiser, Recovering the Unity of the Bible, 115.
} 


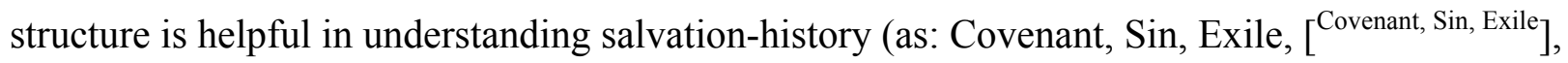
RESTORATION) ${ }^{63}$ to integrate the people of God. As the restoration for Israel is found in Jesus, so is the restoration for humanity found in Jesus. The people of God, therefore, consists of believing Israel included along with believing Gentiles. ${ }^{64}$ This integrated people of God is therefore defined and operates under the same functions as the people of God in the Old Testament, namely being divinely ordained by God, ethically set apart for God, and being missions-minded to communicate God to the world. ${ }^{65}$

As it has been hinted at, with regard to Salvation-History and the people of God, perhaps the underlying element is Covenant. In the same way that the kerygma was an idea broad enough to carry with it other unifying themes, covenant may be that vessel for understanding the entire Bible. Hafemann has argued that the covenant relationship is the idea, similar to that of the kerygma in the New Testament, that unites the entire Bible:

This does not mean that the 'covenant relationship' is the one, central theme of the Bible...More appropriately, the concept of the covenant relationship provides the structure that serves to integrate the interrelated themes developed throughout the history of redemption delineated in the scriptures...the covenant [is] the interpretive lens for seeing clearly the conceptual and historical unity of the Bible in the midst of its diversity." 66

Hafemann explores the covenant relationship in terms of a divine extension of natural familial and tribal relationships. God is thus the great Father and the great King of his covenant people. ${ }^{67}$ According to Hafemann, "the covenants of the Bible all embody [this] same fundamental covenant relationship." 68 Despite the various "covenants" described in the Bible,

\footnotetext{
${ }^{63}$ In his article, Ciampa provides much more visually stimulating charts to display this embedded structure.

${ }^{64}$ See, Ibid., 117.

65 See, Martens, "The People of God," 227-252.

${ }^{66}$ Hafemann, "The Covenant Relationship," 23.

${ }^{67}$ Ibid., 26.

${ }^{68}$ Ibid., 21.
} 
there remains "one, constant relationship between God and people." ${ }^{69}$ Hafemann makes the point that the scriptures are "in answer to the question of who will inherit the covenant promises made to 'Israel' as the true, elect people of God." ${ }^{, 70}$ Returning back to the question of the quandary of relating the two testaments, the answer is not ethnic Israel, but rather, "those within this covenant relationship [who] now belong to God and one another as 'family'. Election, not blood, rebirth, not birth, defines the people of God."71

The search in this paper for an integrative framework of the entire Bible has only scratched the surface. The three concepts presented here, while they are all interrelated (and, not one but three), offer the biblical theologian a great starting point to explore this issue on a deeper level. Using these three ideas to create a compound central theme, it could be stated in this way: in the Bible we see the covenant relationship between God and humanity, throughout salvationhistory, defining who are the people of God.

\section{Implications \& Conclusions}

Proof-texting and Systematic Theology:

If Christians can learn something from the issue of diversity in the Bible, it should be in regards to "proof-texting." One should be wary of presentations of the Bible as a harmonious, homogenous presentation of doctrine because there are indeed different "theologies" in the Bible. ${ }^{72}$ Surely, though, there is a difference between proof-texting and creating a comprehensive systematic theology. Is the implication of biblical diversity that we should not or cannot pursue a systematic theology? The above quotation of Daniel Fuller summarizing Oscar Culmann's

\footnotetext{
${ }^{69}$ Ibid., 30. This is again against the traditional understanding of the Bible as a "conflict"

${ }^{70}$ Ibid., 25

${ }^{71}$ Ibid., 26

${ }^{72}$ Wenham, “Appendix: Unity and Diversity,” 687.
} 
position would seem to suggest as such. It seems that much of the discussion around biblical theology and systematic theology has set these two disciplines at odds. ${ }^{73}$ This is perhaps an area where subsequent and further research would be beneficial. This investigation found one article by D.A. Carson, who argues essentially that while biblical theology and systematic theology form a hermeneutical circle, we can be confident in pursuing a systematic theology. ${ }^{74}$ "Problem" or "Virtue"75

Usually the "problem" of a diverse biblical corpus is discussed within scholarship as something which is less than ideal. Diversity is viewed either as a problem of divinely inspired Scripture, or simply as a problem of early Christian variety, growth, and development. Instead of viewing the concept of diversity as a problem, the Christian should see it as a virtue. With regard to the New Testament, George Ladd has stated that "there is a great richness in the variety of New Testament theology which must not be sacrificed." ${ }^{, 76}$ It is worth noting in this section that the major conclusions of Dunn and others regarding the nature of orthodoxy in the New Testament period have not gone unchallenged. For example, David Wenham has made this point:

[If] there is a danger of reading later orthodoxy into the biblical texts, there is equally a danger of reading a modern, anti-dogmatic, broadly ecumenical spirit into the New Testament... if the diversity of early Christianity is easily exaggerated, the cohesiveness of the early church is easily underestimated. ${ }^{77}$

Why, as Ladd suggests, should the richness of New Testament theology not be sacrificed? I think the answer is two-fold. Otto Betz has suggested an answer which is rather

\footnotetext{
${ }^{73}$ For a distinction between the two, see, Pate et al., The Story of Israel, 11-12. See also, D.A. Carson, "Unity and Diversity in the New Testament: The Possibility of Systematic Theology." in Scripture and Truth (Ed. D.A. Carson and J.D. Woodbridge. Grand Rapids: Baker, 1992), 65-95.

${ }^{74}$ See, Carson, "Unity and Diversity," 91, 94-95.

${ }^{75} \mathrm{I}$ am borrowing these dichotomous terms from Kaiser, Recovering the Unity of the Bible, 25.

${ }^{76}$ George Eldon Ladd, A Theology of the New Testament (Rev. ed. Edited by Donald A. Hagner. Grand Rapids: Eerdmans, 1993), 28.

${ }^{77}$ Wenham, “Appendix: Unity and Diversity,” 715. See also Carson, “Unity and Diversity,” 71-95.
} 
profound. In the New Testament, we see in the variety of perspectives a certain "principle of freedom which was inaugurated by Jesus himself." ${ }^{, 78}$ In addition, in the diversity of perspectives that we find in the New Testament, we find a mirror into the state of the modern church, where different traditions have come to emphasize different theological leanings. As we find unity in the writings of the New Testament around concepts like the kerygma, it should be a reminder to the present church at large of our common mission. The richness should not be sacrificed because it reminds us of who we are. To summarize, Freyne and van Wolde offer the following analogy: "Faced with the mystery of divine self-communication, plurality and difference... should be seen positively as a gift to be celebrated, a symphony rather than a cacophony." 79

\section{The Christian's Scripture:}

This paper began its endeavor with the fundamental conviction that the Bible is God's revelatory Word to humanity. As such, the issues discussed here are important to Christian theology as a synthesis of biblical theology. As G. Ernest Wright states, "The problem of the unity of the Bible is one of serious and critical concern to those who believe that biblical theology must always be the proper setting and background for the church's theology." The conclusions one makes with regard to these issues influence one's view of God and the nature of Scripture ${ }^{81}$ Similarly, one's view of God and the nature of Scripture influence the way one approaches this topic. Despite this hermeneutical circle, it can be maintained with confidence that unifying elements can be identified (both at the level of the New Testament and

\footnotetext{
${ }^{78}$ Betz, "The Problem of Variety and Unity," 8.

${ }^{79}$ Freyne, and van Wolde, The Many Voices, 7.

${ }^{80}$ G. Ernest Wright, "The Unity of the Bible." Interpretation 5 (1951): 131-133.

${ }^{81}$ See also, Wenham, “Appendix: Unity and Diversity," 687.
} 
at the level of relating the two Testaments) so that we can achieve a "whole Bible biblical

theology."

\section{Bibliography}

Barr, James. "Trends in Biblical Theology.” Journal of Theological Studies 25 (1974): 265-282.

Betz, Otto. "The Problem of Variety and Unity in the New Testament." Horizons in Biblical Theology 2 (1980): 314.

Brown, Raymond E. The Community of the Beloved Disciple. New York: Paulist Press, 1979.

Bultmann, Rudolph. Theology of the New Testament. 2 vols. Translated by Kendrick Grobel. Waco, Baylor University Press, 2007.

Carson, D.A. Unity and Diversity in the New Testament: The Possibility of Systematic Theology." Pages 65-95 in Scripture and Truth Edited by D.A. Carson and J.D. Woodbridge. Grand Rapids: Baker, 1992.

Ciampa, Roy E. "The History of Redemption.” Pages 254-308 in Central Themes in Biblical Theology: Mapping Unity and Diversity. Edited by S.J. Hafemann and P.R. House. Grand Rapids: Baker Academic, 2007.

Dodd, C.H. The Apostolic Preaching and its Developments. London: Hodder \& Stoughton, 1936.

Dunn, James D.G. and James P. Mackey eds. New Testament Theology in Dialogue. Philadelphia: Westminster, 1987.

. Unity and Diversity in the New Testament: An Inquiry into the Character of Earliest Christianity. $2^{\text {nd }}$ ed. London: Trinity Press International, 1990.

. The Theology of Paul the Apostle. Grand Rapids: Eerdmans, 1998.

Freyne, Sean, and Ellen van Wolde, eds. The Many Voices of the Bible. Concilium 2002:1. London: SCM Press, 2002.

Fuller, Daniel P. The Unity of the Bible: Unfolding God's Plan for Humanity. Grand Rapids: Zondervan, 1992.

Gloer, W. Hulitt. "Unity and Diversity in the New Testament: Anatomy of an Issue." Biblical Theology Bulletin 13 (1983): 53-58.

Hafemann, Scott J. and Paul R. House, eds. Central Themes in Biblical Theology: Mapping Unity and Diversity. Grand Rapids: Baker Academic, 2007.

. "The Covenant Relationship." Pages 20-65 in Central Themes in Biblical Theology: Mapping Unity and Diversity. Edited by S.J. Hafemann and P.R. House. Grand Rapids: Baker Academic, 2007.

Hunter, A.M. The Unity of the New Testament: One lord, One Church, One Salvation. London: SCM Press, 1943.

Kaiser, Walter C. Jr. Recovering the Unity of the Bible: One Continuous Story, Plan, Purpose. Grand Rapids: Zondervan, 2009.

Jeremias, Joachim. The Central Message of the New Testament. New York: Charles Scribner's Sons, 1965. 
Ladd, George Eldon. A Theology of the New Testament. Rev. ed. Edited by Donald A. Hagner. Grand Rapids: Eerdmans, 1993.

Lohse, Berhard. Martin Luther: An Introduction to His life and Work. Translated by, Robert C. Schultz. Philadelphia: Fortress Press, 1986.

Martens, Elmer A. "The People of God." Pages 225-253 in Central Themes in Biblical Theology: Mapping Unity and Diversity. Edited by S.J. Hafemann and P.R. House. Grand Rapids: Baker Academic, 2007.

Pate, C. Marvin, J. Scott Duvall, J. Daniel Hays, E. Randolph Richards, W. Dennis Tucker Jr. and Preben Vang. The Story of Israel: A Biblical Theology. Downers Grove: IVP Academic, 2004.

Reumann, John. Variety and Unity in New Testament Thought. New York: Oxford University Press, 1991.

Wenham, David. "Appendix: Unity and Diversity in the New Testament." Pages 684-720 in A Theology of the New Testament. By George Eldon Ladd. Rev. ed. Edited by Donald A. Hagner. Grand Rapids: Eerdmans, 1993.

Wright, G. Ernest ${ }^{(1)}$. “The Unity of the Bible.” Interpretation 5 (1951): 131-133.

Wright, G. Ernest ${ }^{(2)}$. “The Unity of the Bible.” Scottish Journal of Theology 8 (1956): 337-352. 